\title{
冷間圧延加工されたせんい強化複合材料の変形挙動と 引張強さの混合則からの偏倚
}

\author{
落合庄治郎* 水原誠* 村上陽太郎**
}

\begin{abstract}
Shojiro Ochiai, Makoto Mizuhara and Yotaro Murakami : Deformation Behaviour and Deviation from the Simple Rule of Mixture for the Ultimate Tensile Strength in the Cold Rolled Fibre-Reinforced Composites. The cold rolling characteristics of ductile fibre-reinforced $\mathrm{Mo} / \mathrm{Cu}, \mathrm{Mo} / \mathrm{Cu}-\mathrm{Cr}$ and $\mathrm{W} / \mathrm{Cu}$ composites prepared by vaccum infiltration technique have been investigated. These composites were cold rolled parallel or perpendicular to fibres in steps of $10 \%$ reduction in thickness to maximum $90 \%$. Deformation behaviour of composites as well as matrix and fibre separately were studied. Tensile tests were carried out. Tensile strength values of the Mo/Cu composites agreed well with those calculated from the rule of mixture in which work hardening of fibre and matrix was considered. In the $\mathrm{Mo} / \mathrm{Cu}-\mathrm{Cr}$ composites, the tensile strength showed lower values than those calculated from the rule of mixture, probably, according to damages by cold rolling of Mo-Cr solid solution layers formed at interfaces of Mo fibres during preparation. In the $\mathrm{W} / \mathrm{Cu}$ composites, the tensile strength had maximum values at $30 \sim 40 \%$ reduction in thickness because of a lower ductility of $\mathrm{W}$ fibres.
\end{abstract}

(Received November 17, 1972)

\section{I. 緒言}

ボロンせんい(1)や一方向共晶凝国して $\mathrm{Al}_{3} \mathrm{Ni}$ 化合物 で強化した複合材料に及はすす冷間龙延加工の影響につい

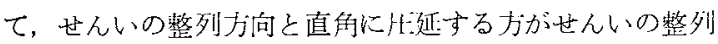

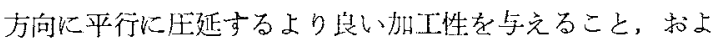
び一是の加工率のところで引張强さはピークを示すことが 現在まで報告されているが，靸性さんいで強化した複合 材料の機械的，組織学的性算に及妨す加工の影暗について の報告はなく $\mathrm{Nb} / \mathrm{Cu}$ 系複合材料の作製 ${ }^{(3)}(4)$ か ら推測され るにすぎない。

著者らは時效性 Cu-Cr 合金をマトリックスにした複合 材料について，せんいにW線を用いた場合はW線界面に生 成するW-Cr 固溶体層のため引张強さが著しく低下する が，せんいにMo線を用いた場合はMo 線界面の Mo-Cr 固溶体層の生成にもか力わらず引張強さ，降伏応力ともに 上昇し，時効処理に上る効果が認められたことを報告し $た^{(5)}$.

本研究では上記研究をさらに進めてせんいにWまたは Mo 線，マトリックスに純銅または時效性 $\mathrm{Cu}-\mathrm{Cr}$ 合金を用

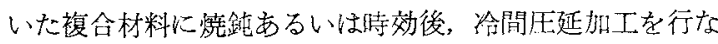
い変形挙動を観察，検討することおよびマトリックスなら びに奴いの組織と強度を变化させ，引張試験を行なって 破断挙動を観察するとともに引張強さを求め，简単な塑件

* 京都大学大学院 (Graduate School, Kyoto University, Kyoto)

** 京都大学工学部治金学教室 (Department of Metallurgy, Faculty of Engineering, Kyoto University, Kyoto)

(1) J.R. Getten and L. J. Ebert : Trans. ASM, 62 (1969), 869.
力学で予想される鼬合則と比較㛟討し，注合則からの偏倚 の原因を洘察することを目的とした。

\section{II. 実 験 方 法}

マトリックスはリン脱酸銅または $\mathrm{Cu}-0.40 \% \mathrm{Cr}$ 合金を， せんいは $100 \mu$ のW線または $100 \mu$ および $500 \mu$ の $\mathrm{Mo}$ 線 の連紿诗んいを使用した。せんい表面はェメリ一紙で軽く 研摩後，飽和水酸化ナトリウム溶液で惹沸洗浄した，生延 用試料はグラファイトの鋳型中にせ几いを整列させ釷型ご 上石英管中に雨入し，10-3 $\mathrm{mm} \mathrm{Hg}$ の真空中で純銅西るい は Cu-Cr 命金を含没させ，せんいの整列加向の長さが 40 $\mathrm{mm}$ ，それと直牦少向の長さが $20 \mathrm{~mm}$ ，厚さが $2 \mathrm{~mm}$ の形 状でせんい容積率 $25 \%$ および $40 \%$ のものを作製した。溶 解温度は $1160^{\circ} \mathrm{C}$ とし 30 分閒溶融状態を保った後, 試料下 方より凝固させ約 $600^{\circ} \mathrm{C}$ まで炉冷後とり出した。純銅をマ

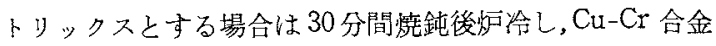
をマトリックスとする場合は $1000^{\circ} \mathrm{C} て ゙$ 溶体化処理後, $475^{\circ} \mathrm{C} て ゙ 5$ 時間時効処理を行なった。使用した压延機は四 段ロールで,ワークロールの直径は $50 \mathrm{~mm} \phi$, 油潤滑を行な

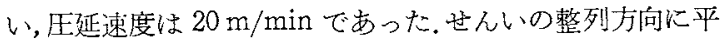
行および直角に冷間死延加工行ない 1 国の玨延につき最 初の板厚の $10 \%(0.2 \mathrm{~mm})$ ずつ厚さを淢少させ最大の板厚 の減少率 $90 \%$ とした(以後最初の板厚に対寸る板厚の娍

(2) M. Salkind, F.George and W.Tice : Trans. Met. Soc. AIME, 245 (1969), 2339.

(3) B.P.Strauss and R.M. Rose : Phys.Letters, 25 A (1967), 362

(4) H.E.Cline,B.P.Strauss, R.M.Rose and J.Wulff: Trans.ASM, 59 (1966), 132.

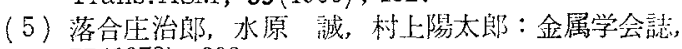
$37(1973), 208$. 
少率を加工率と呼ぶ)。引張試験では試料の平行部長さは $20 \mathrm{~mm}$, 雨速度は $0.025 / \mathrm{min}$ とし，常にせんいの整列方向 に引張荷重を与えた。破断した試料は光学䡩微鏡および走 查型電子顕微鏡により, マトリックスおよびせんいの破断 挙動を観察した。

\section{III. 実 験 結 果}

1. 冷間圧延加工による複合材料，マトリックスおよび せんいの变形挙動

\section{（1）せんいに Mo 線を用いた場合}

Photo.1 は純銅をマトリックスとしMo 線をせんいとし た複合材料 (以下 $\mathrm{Mo} / \mathrm{Cu}$ 複合材料子略称)をせんいの整列 方向に平行に圧延し，せんいの整列方向に直角の断面を示 したものである.Mo線はだ円形に変形していて後述の W/Cu 複合材料とはちがい,おのおののせんいは持同じ 断面皘を示し，せんいが複合材料内部でマルティプルネッ キングを扣こすことはなかった。この複合材料ではマトり ックスの及ならずMo 總の変形电行なわれており，ボロン せんいて強化したアルミニウムの場合が強加工を加えても ボロンせんいは塑性変形せず，ただ損陽，破䉼をうけるだ けであるのに比して大きな特徴である。

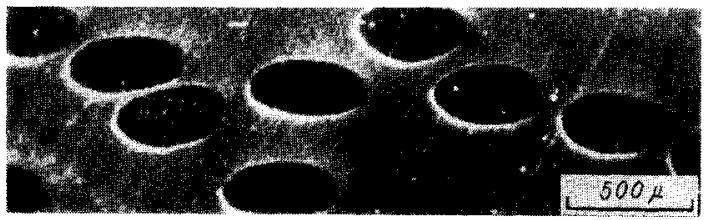

Photo.1 Cross sectional plane of $\mathrm{Mo} / \mathrm{Cu}$ composite cold rolled $70 \%$ parallel to fibres

Fig.1はせんいの整列方向に平行および直角に生延を加 交た複合材料の断面積の变化を胿延前の試料の断面積を 1

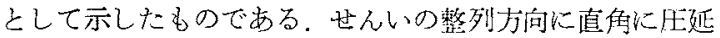
した場合には，せんいの整列方向と直角方向にのみ広が
り，せんいの整列方向にはほほととど伸びず，試料の断面積 はやや低下の傾向はあるが，棌涪一定と及なしてよい，せ んいの整列方向に平行に压延した場合，女んいの整列方向 に著しい伸びが起こり，をれと直角方向にはわずかの伸び しか起らず，せんいの整列方向に直角な断面では著しい断 面積の減少を伴い，90\%の王延では $\mathrm{Mo} / \mathrm{Cu}-\mathrm{Cr}$ 複合材料 でもとの約 $14 \%$ の断面積に減少した。亦た $\mathrm{Mo} / \mathrm{Cu}$ 複合材 料に比して $\mathrm{Mo} / \mathrm{Cu}-\mathrm{Cr}$ 複合材料の子が断面積の減少は著

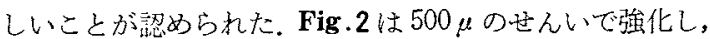
せんいの整列方向に平行に圧延した複合村料中のせんい の断面積 $S_{f}$ ，だ円形となったせんいの長軸長さ $2 a$, 短朝 長さ $2 b$ を加工率に対して示したものである。 $S_{f}$ 惊顕微鏡 写真から求めたが， $a b \pi$ としての計算から求めた值とき方 めて上い一致を示し，せんい断面は完全に近いだ円形であ

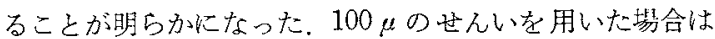
せんい間隔は小さくなり加工により隣接せんいの影響をう けて，だ円からの偏倚がみられた，一方比較の目安として


圧延してみたところ断面はその横幅が約 $1800 \mu$ の矩形に 近い形状となったが，複合材料中では前述のごとくだ円形 となり長軸長さは加工率が增加しても注济一定であったか ら，せんいは弾独で压延した場合に比して著しく異なった 変形举動を示している. Fig.3 はせんいに平行に庄延した 場命のせんいとマトリックスの変形量の差に起因するせん い容積率 $V_{f}$ の变化が模在するか否か，存在すればどの程 度かをせんいの整列方向们直角な複合忉料の断面積と世ん いの断面積から $V_{f}$ を計算して调べたものであるが，加工 前後で $V_{f}$ は活添一运であった。少んいの整列方向に直角 に圧延した場合も同様にせんいの整列少向に直角な断面で V/の変化は見られなかったが，これは压延してもせんい の整列方向の伸びが汪とんどなかったことからむ明らかで ある．Fig.4 は複合材料をせんいの整列方向に圧姬した場 命の伸びを示したもので，その伸びの差は幅広がりの差に

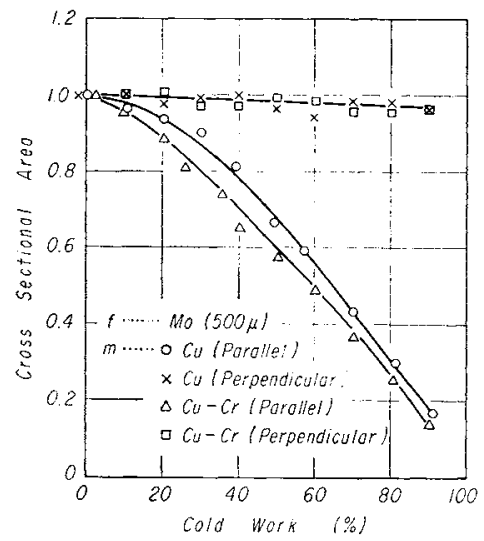

Fig. 1 Change of cross sectional area of $\mathrm{Mo} / \mathrm{Cu}$ and $\mathrm{Mo} / \mathrm{Cu}-\mathrm{Cr}$ composites caused by cold rolling parallel or perpendicular to fibres

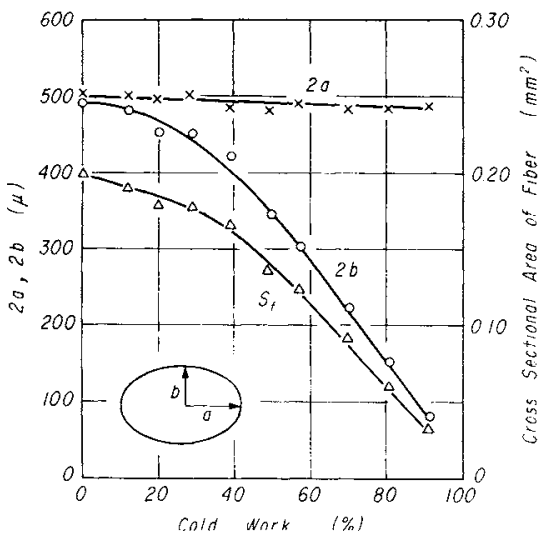

Fig.2 Effect of cold rolling parallel to fibres on the shape and cross sectional area of fibres in $\mathrm{Mo} / \mathrm{Cu}$ composites

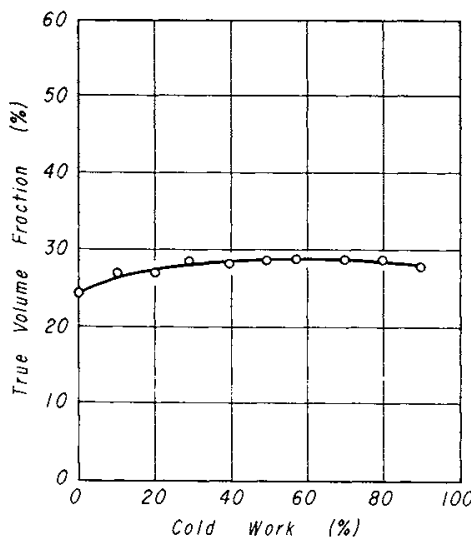

Fig. 3 Change of volume fraction of fibres in $\mathrm{Mo} / \mathrm{Cu}$ composites cold rolled parallel to fibres 


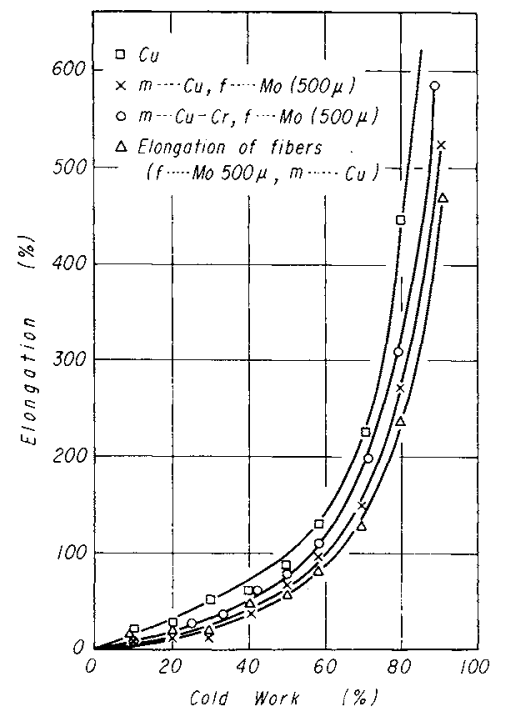

Fig. 4 Elongation of composites caused by cold rolling parallel to fibres

よるものである。断面積を測定し，体積一走条件から計算 したせんいの伸びは，複合材料の伸びに比して著干低い值 学示している。このことから弱いせんいの破断あるいはせ んい同志の交攴による破断が㧍こり，せんいの伸びととも に破断せんい間の空洞部にの場合にはマトリックスが塑 性流れを扣こして空洞部に入っているのが琹められたのの 局部的な変形炕よる伸びへの笴与も存在すると推定され る、純銅をマトシックスとした場合，複合材料の俦びはメ 印，せんい断面䅡から推定した伸びはロ印で示してある が×印から、印を引いた分が破断せんい閒の空洞，また は入りこんだマトリックスの伸びによる寄与であると思わ れる。この潘か、 $V_{f}$ 龙大きくした場合 $\left(V_{f}=0.40\right)$ および， $100 \mu$ の細いせ九いで強化した場合 $\left(V_{f}=0.25\right)$ はせんい の整列方向の伸びは $500 \mu$ の女んいで強化した $V_{f}=0.25$ の Mo/Cu 複合材料に比して小さいことが認められた。

（2）せんいにW線を用いた場合

Fig.5に示したごとく本赛験における正延条件ではせん いの整列方向に平行に压延しても80\%以下の加工率では, せんいの整列方向の伸び $e_{c}$ より，せんいの整列方向之直角 万向の增加 $w_{c}$ が大きく，90\%の加工率になってはじめて 前者が後者より大きくなる．Mo/Cu，Mo/Cu-Cr 複合材料 では $e_{c} \gg w_{e}$ であったから W/Cu複合材料はこれらに比し て著しく異なった変形挙動を示している。亦た加工率が 70\%以上でせんいの整列方向の伸びが急激に增加するが， これはPhoto.2 に示したごとく压延後せんいが破断され ていることから，压延により破断したせんい間の空洞ある いはその部分に入りこんだ銅が局部的に変形して著しい伸 びを示すことに起因すると推定される。亦たW線はせんい の整列方向に平行に生延するとマルティブルネッキングを 示し、W線も引張試験での破断伸び以上の伸びをしている

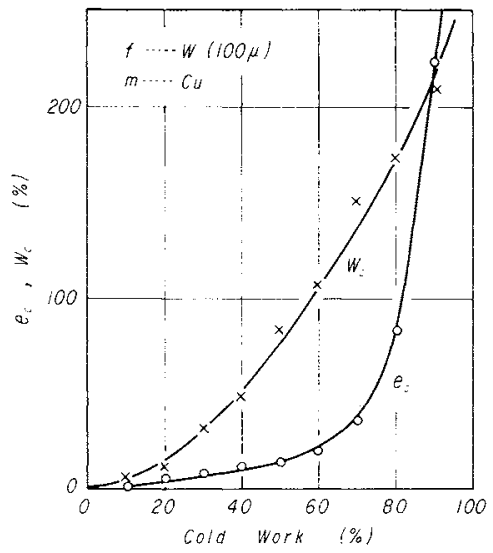

Fig. 5 Change of values of $e_{c}$ and $w_{c}$ of $\mathrm{W} / \mathrm{Cu}$ composites cold rolled parallel to fibres

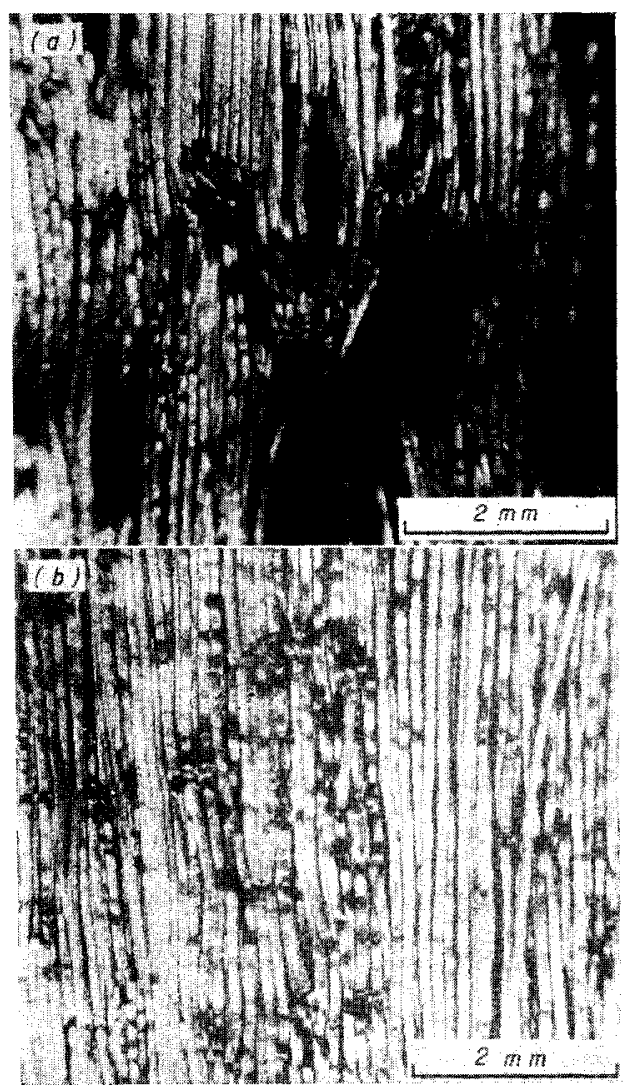

Photo.2 Appearance of $\mathrm{W}$ fibres in the cold rolled W/Cu composites

(a) Cold rolled $80 \%$ parallel to fibres. Some fibres are broken in bundles

(b) Cold rolled $90 \%$ parallel to fibres

ことを示している．Wせんいのマルティブルネッキングは $\mathrm{W} / \mathrm{Cu}{ }^{(5)}, \mathrm{W} / \mathrm{Cu}-\mathrm{Zn}^{\left({ }^{(6)}(7)\right.}$ の単純引張でも見られるが，こ のような $V_{f}$ の大な試料中でみられたのは著者らの知る

(6) C. Schoene and E. Scala : Met. Trans., 1(1970), 3466.

(7) R.M.Vennett, S.M.Wolf and A. P. Levitt : Met. Trans., $1(1970), 1569$. 
かぎりこれが最初である。次にせんいの損傷を調べるため せんいの整列方向に平行に庄延加工をらけた複合材料から マトリックスを稀䃒酸で注意深く溶解して破断していない せんいをとり出した。、Wせんいは新温で稀硝酸と成応しな いのでせんいに変化を少党ず取り北すことがでさたと思わ

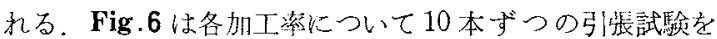

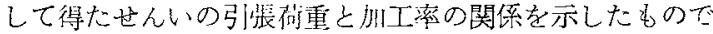
ある。加工率の増大とともにせんいは損傷をらけること， およびマルティプルネッキングを示すことが原因でせんい の引張荷重は減少している。㐬た同洔に行なった破断伸び の測定でも伸びはか工为の堌かとともに減少するのが隹め られた。

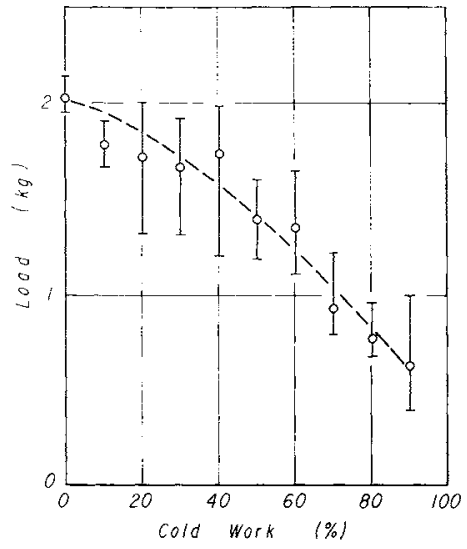

Fig. 6 Effect of cold rolling parallel to fibres on the tensile load of the fibres in $\mathrm{W} / \mathrm{Cu}$ composites

\section{2. 引張試験結果}

（1）せんいに Mo線を用いた場合

Fig.7, Fig.8, Fig.9 は Mo/Cu 拈よび $\mathrm{Mo} / \mathrm{Cu}-\mathrm{Cr}$ 複㝓 材料の弓張試験結果を示したものである。 $\mathrm{Mo} / \mathrm{Cu}$ 複含材 料では，せんい、整列方向に平行，直角いずれの方向にH:
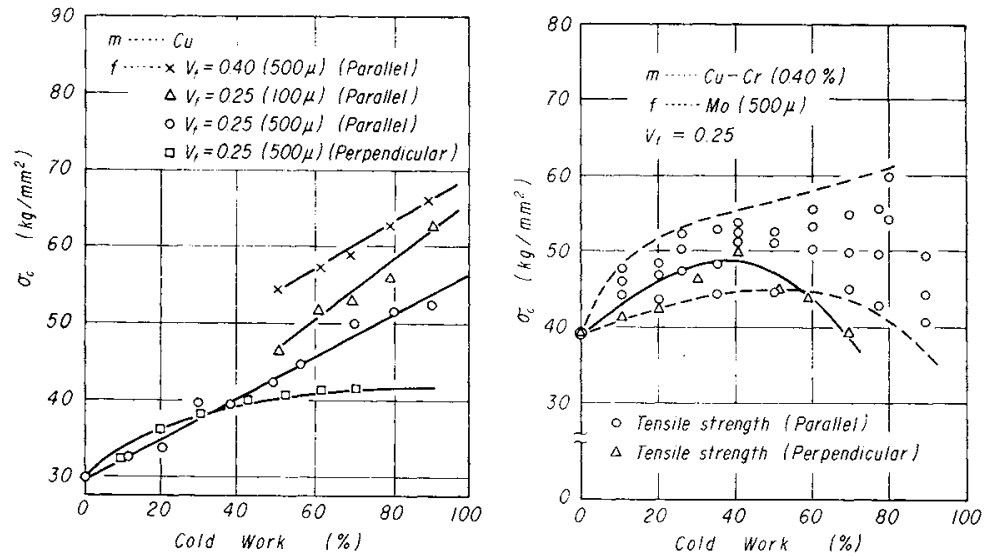

Fig.7 Effect of cold 10lling parallel Fig.8 or perpendicular to fibres on the tensile strength of Mo/ Cu composites
延しても加工率の增加とともに引張強さは上昇したが， $\mathrm{Mo} / \mathrm{Cu}-\mathrm{Cr}$ 複合材料では引张強さはバラッキが大きく30\% の加工率まではほぼ上帠したが，それ以上の加工率では上 昇するものも贷下するすのもみられた。試料作製時のせん いの不整列に起因寸るせんい同心の交果は十分注意しても 起こることが観察されたが，そのよらな交羿の起こる度合 はマトリックスが純銅であっても $\mathrm{Cu}-\mathrm{Cr}$ 合金であってる 弫同じで西ると思われるにもかかわらず，Cu-Cr 合金を マトリックスにした場合には㖊张強さは後に述べる混合則 から予想される值に比して低下した。この原因については 後で考察の部分で議馀する。マトリックスがいずれの場合 も，也九いの整列力向に平行に艮延した場合は常に直角に 玨延した場合より大きな引張強さをもっている。この理由 は後に示す変形挙動に関する考察加ら，せんいの整列方向 に平行に王延した昜合は世儿い，マトリックスと当に变形 在うけるが，世んいの整列方向に直角に圧延した場合はマ トリックスの変形が主であることに起因すると思われる。

\section{（2）せんいにW線を用いた場合}

W/Cu 複合材料の引張強さを Fig.10に示した。引滈強 さはせんいの整列方向に平行，直角いずれの方向に非延し ても卧 30〜40\%の加工辩でピークとなりその後低下し た、こ机はW線が Mo 線に比して靱性に少るためマトリッ クスに间じ純鈳を用いても加工によるせんいの損傷，破断 をらけやすいこと，およびマルティプルネッキングにより 局部的に $V_{f}$ が低下することがその主原因であると思われ る.とくに Photo.2(a)で示したよらにWせんいが束状で 破断すれば引張強さは著しく低下すると考学られる。せん いの整列方向に平行に医延した場今の活が，直角に压延し た場合より，大きな引掁強さを示したが，この傾向は Mo/ $\mathrm{Cu}, \mathrm{Mo} / \mathrm{Cu}-\mathrm{Cr}$ 複合材料の照合と闹じである。

\section{3. 圧延組織および破断面の観察結果}

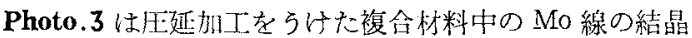

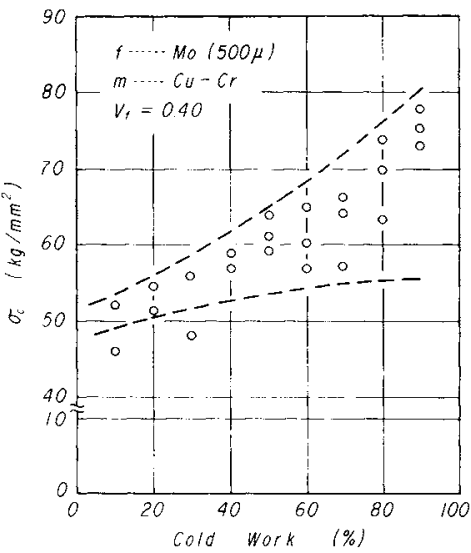

Effect of cold rolling parallel Fig. 9 Effect of cold rolling parallel or perpendicular to fibres on the tensile strength of $\mathrm{Mo}$ Cu-Cr composites. $V_{f}=0.25$ to fibres on the tensile strengh of $\mathrm{Mo} / \mathrm{Cu}-\mathrm{Cr}$ composites. $V_{f}=0.40$ 


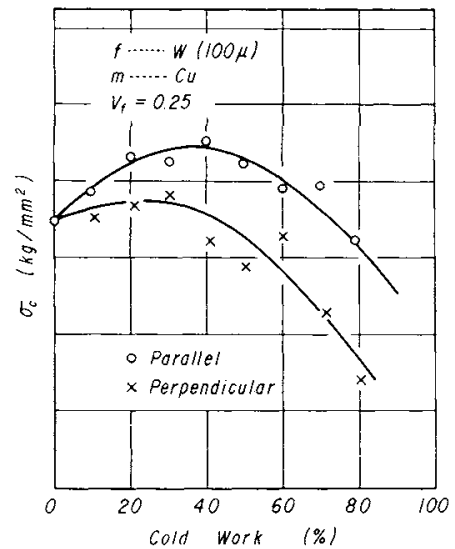

Fig. 10 Effect of cold rolling parallel or perpendicular to fibres on the tensile strength of $\mathrm{W} / \mathrm{Cu}$ composites

101

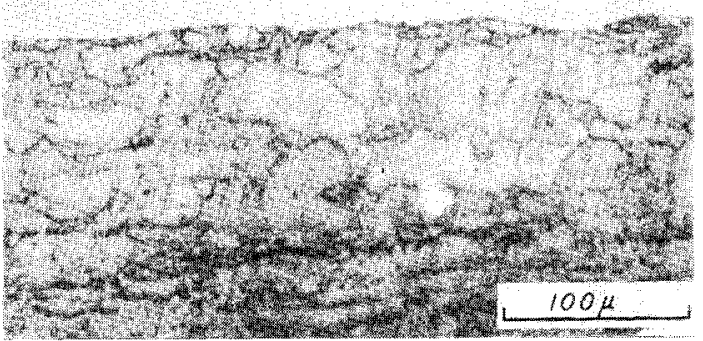

(b)

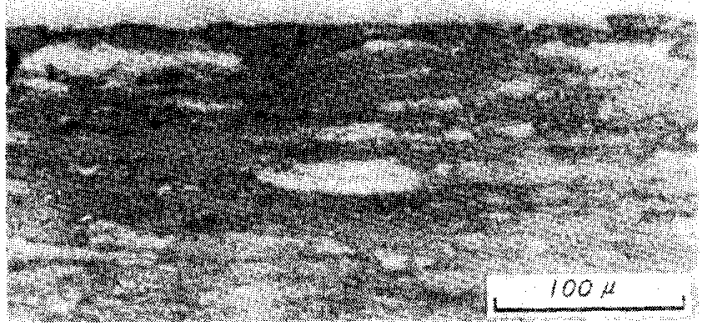

Photo.3 Grain structure of Mo fibres in the cold rolled $\mathrm{Mo} / \mathrm{Cu}$ composites

(a) Cold rolled $70 \%$ perpendicular to fibres

(b) Cold rolled $90 \%$ parallel to fibres

粒の光学頙微鏡組織を示したもので，せんいの整列方向に 直角に压延した場合（a）は結晶粒の变形の度合は小さいが， 平行に圧延した場合 (b)は，せ九いの長さ方向に結晶粒は引 きのばされていて，せんいの変形のうけかたには大きな差 のあることが明瞭に示されている.Photo.4は W/Cu 複合 材料をせ九いの整列方向に平行に压延した場合に見られる W線のマルティプルネッキングを(a) 光学顕微鏡，(b)走查 型電子顕微鏡で観察したものである. 50\%以上の加工率で は活とんどすべてのせんいが試料長さ全体にわたってマル ティプルネッキングを抗こしていた．Photo. 5 は Mo/Cu 複合材料でせんいの整列方向に $50 \%$ 日延加工した試料の

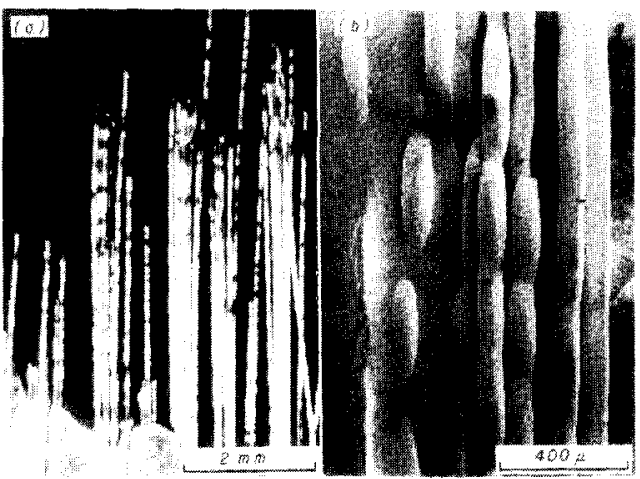

Photo.4 Multiple necking of $\mathrm{W}$ fibres in $\mathrm{W} / \mathrm{Cu}$ composite cold rolled $80 \%$ parallel to fibres. Matrix was etched to remove

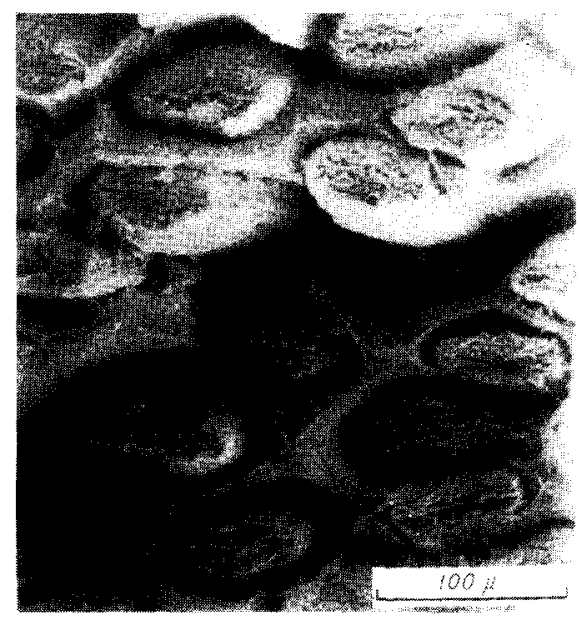

Photo.5 Appearance of fracture surface of $\mathrm{Mo} / \mathrm{Cr}$ composite cold rolled $50 \%$ parallel to fibres

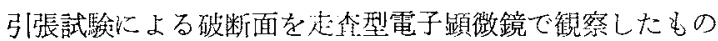
でせんいはネッキングにより破䉼している。またこの马 真に示されるよ5に $100 \mu$ のせんいを用いた場合は隣接せ んいの影響でせんい断面は完全なだ形になるとは限らな

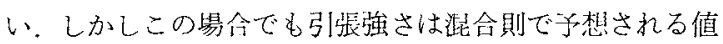
になり，Wせんいに比してMo せんいの大きい変形能が 压延加工による損傷を最小限にくいとめる要因となってい る.

\section{IV. 考察}

\section{1. 圧延加工による変形挙動}

Mo/Cu 複合材料を例にとって考光た場合, Fig.12, Fig. 13 の×印はそれぞれせんいの整列方向に平行あるいは直 角に压延した複会材料中の Mo 線のヴィッカース硬度から 推定した引張強さであるが両者の間には大きな差がある。 せんいの加工硬化はせんいの整列方向に直角に目延した場 合は，せんいの加工硬化は平行にた延した場合添ど大きく ない.Photo.3とも考光あわせると，せんいの整列方向に 平行あるいは直角に压延老加えた場合，それぞれせんいお 
よびマトリックスの変形のうけかたが異なることを意味す る. せ九いの整列方向に平行に压延加工した場合，Fig.2 ではせんい断面の長軸方向の変化はほとんどなかったが, 複合材料の幅広がり虫存在する。しかし $w_{\mathrm{c}}$ は $e_{\mathrm{c}}$ の 1 程 度であり，きわめて近似的には，せ九いとマトリックスは

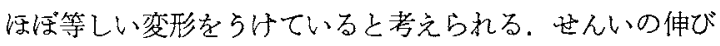
がマトリックスより少し小さいが注ば等しいという結果 は、专れ毕れの純粋变形抵抗は異なっているため, 压延時に は, せんいは引張, マトリックスは圧縮の付加的沁力をら けていると考えなけ礼ばならない(8)。この付加的応力の存 在が好んいの整列方向に压延した場合にせんいと、トリッ クスの変形量を等しくし $V_{f}$ をとんど変化させない原因 になると考之られる。好んいの整列方向之直角方向へのマ トリックスの広がりは $V_{f}$ をか光ることにはならないから である、一方世んいの整列方向に值角に圧延した場合は，平 行に压延した場合に比して，同じ加工率でせんいの加工硬 化が小さい.このことはマトリックスの変形量が大きいこ とを示している。これはせんいの整列方向に平行に任延し た場合は，せんいはマトリックスの自由なすべりを阻止す る因子となりらるのに対し，直角に圧延した場合は各せん い間帅あるマトリックスですべりが容易に行なわれるため と思われる(2)。この場合には付加的応力の存在はなく、ま たせんいとマトリックスの変形量も異なっている。ただし Fig.13にみられるごとく Mo 線も変形をらけているから， 変形举動のすべてをマトリックスのすべりのみで記述でき るわけではない，この場合もせんいの整列方向に直角な試 料断面で $V_{f}$ が変化しないことはすでに述べたとおりであ る.以上の変形挙動は一力向凝固 $\mathrm{Al}-\mathrm{Al}_{3} \mathrm{Ni}$ 共晶複合合金 を $\mathrm{Al}_{3} \mathrm{Ni}$ に平行に圧延した場合は $\mathrm{Al}_{3} \mathrm{Ni}$ にラックが入 るが， $\mathrm{Al}_{3} \mathrm{Ni}$ に直角に压延した場合は $\mathrm{Al}_{3} \mathrm{Ni}$ を傷つけない で大きな加工率が得られる(2)ことに対応している。

\section{2. 引張強さ}

本実駼で用いた MoおよびWのよらなせんいを有する複 合材料儿冷間圧延加工を加之た場合，それらの試料の引張 強さに影響を与える因子としては次の上らなものが考えら れる。

(イ）せんいの加工硬化

(ロ) マトリックスの加工硬化

（八）せんいの損傷に起因するせんいの引張強さの低下

(二) せんいの破断に起因する有効せんい容積率の減少

（ホ）せんいの損傷部, 破䉼部での応力集中

（へせんいとマトリックスの変形量の差に起因するせ 九い容積率の增大

（ト）マトリックスのクラック阻止能力の低下

（チ）試料作製時の残留応力の加工による機械的解放

（リ）通常の加工により導入される残留応力およびせん いとマトリックスの変形能の差に起因する残留応 力

(8) A.G.Atkins and A.S. Weinstein: Inter.J.Mech. Sci, $12(1970), 641$.
（又）集合組織

（ル）複合材料の加工による特異挙動 (たとえばW 線の マルティプルネッキング）

以下，簡単のためせんいに Mo 線を用いた複合材料のみ

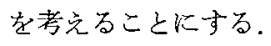

せ九いの整列方向に平行に王延した場合は压延加工によ る塑性歪を単純引張によるをれに相当塑性歪の考光方を用 いて換算すれば(せんいとマトリックスの変形量は、は注等 しいので, 同一雨をらけていると考えられるので，複合材 料の強度は混合則上り圧延加工，おょび引涱を通じて，一 つの式で記述される。この場合压延変形中に存在する付加 的応力は压延後はマトリックスの降伏強さ程度の残留応力 として残るが，混合則による引张強さの推定には，せんい とマトリックスの加工硬化のみを考光ることにして議論を 進め, 後汇考察する。一方せんいの整列方向偪南に压延 した場合は生延加工中にせんいとマトリックスに同一露が 考穴られないため，せんいの整列方向に平行に压延した場 合と同じとりあつかいはできない，ただし引張試験ではせ んいの整列方向に引張荷重を与えているので，圧延および 引張によるせんいとマトリックスのそれぞれの変形量がわ かれば(本実験ではわからなかったが)，その变形量に対応 して強度が計算され，それぞれの容積率を乘じ加算するこ とによって涱強さも推定されるはずである(せんいの整 列方向に平行, 直角心ずれの方向に压延しても $\mathrm{Mo} / \mathrm{Cu}$, $\mathrm{Mo} / \mathrm{Cu}-\mathrm{Cr}$ 複合材料ではせんいの整列方向に直角な断面で $V_{f}$ の変化がないのはすでに述べたとおりである).以下で はまず，せんいとマトリックスの変形量が異なる場合の一 般的な取り扱いを行ならこととする。

次いでせんいとマトリックスの加工硬化から予想された 複合材料の引張強さと実㵋值を比較检討することによっ て, 引張強さの低下やバラッキに対して(ハ)〜(ル)のどの 因子が最も大きな影響を与えているかを議論する。

複合材料の引張強さは次式で与えられる。

$$
\sigma_{c}=\sigma_{f} V_{f}+\sigma_{m}^{*} V_{m}
$$

$\sigma_{m}^{*}$ は複合材料の破断侍にマトリックスの負担する応力で， $V_{m}$ はマトリックスの容積率である。 女九いの整列力向に

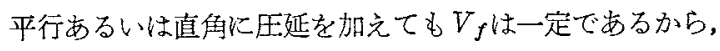

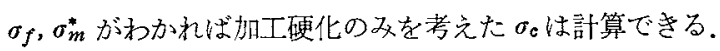

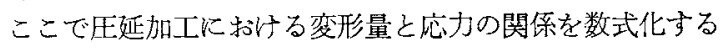
ために一般に塑性力学で使用される数式のなかで, 最も取 り扱い易い式†。

$$
\sigma=F(\bar{\varepsilon})^{n}
$$

を適用することを考学てみる。(2)は本来, 応力一歪曲線 を近似する式で, $\sigma$ は真応力, $\bar{\varepsilon}$ は真歪み, $n$ は単綝引張で の引張強さを示す時点での真歪み，Fは定数であるが，正

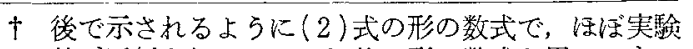
值が近似された。しかし他の形の数式を用いても， 以下の議論の進め方は，同様に行ならことができ る. 
延加工の場合はをに相当塑性歪を用いると Mo，Cu および $\mathrm{Cu}-\mathrm{Cr}$ 合金の相当空力－相当塑性歪曲線を近似できる( ${ }^{(9)}$. ただし旦延时の摩擦抵抗起因する試料表面部の剪断変形 は試料中の各せんいのビッカース硬度に大きな差が見られ なかったこと，扣よび試料両端部における板表面部分の張 出しが任とんどなかったことから小さいと考えられるの でこの場命には然視して相当塑性歪を計算することにし


すれ化

$$
\sigma_{u}=F \cdot(n / e)^{n}
$$

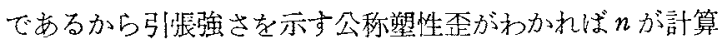
でき， $\sigma_{w}$ と $n$ 在（3）式に代入すると $F$ が計算できる，本 実駼では $\mathrm{Mo}, \mathrm{Cu}$ および $\mathrm{Cu}-\mathrm{Cr}$ 合金の引张強さとその点 に护计る公称塑性雨は各々，平均 $74.5 \mathrm{~kg} / \mathrm{mm}^{2}, 20 \%, 14$ $\mathrm{kg} / \mathrm{mm}^{2}, 35 \%$ およ゙ $29.5 \mathrm{~kg} / \mathrm{mm}^{2}, 26 \%$ あったので $\mathrm{Mo}, \mathrm{Cu}$ および $\mathrm{Cu}-\mathrm{Cr}$ 会金の真応力-真雨曲線は

$$
\begin{aligned}
& \sigma_{\mathrm{Mo}}=121.9(\bar{\varepsilon})^{0.182} \\
& \sigma_{\mathrm{Cu}}=26.7(\bar{\varepsilon})^{0.300} \\
& \sigma_{\mathrm{Cu}-\mathrm{Cr}}=51.9(\bar{\varepsilon})^{0.231}
\end{aligned}
$$

と近似でき，せんい，マトリックスの不延による相当塑性 歪と引隈試験による塑性歪との租がそれぞれ， $\bar{\varepsilon}_{f}, \bar{\varepsilon}_{m}$ の時 点ての $\mathrm{Mo} / \mathrm{Cu}$ 複合材料の过九いの整列方向に亩角な断面 での引晨 (真) 応力 $\sigma_{\mathrm{C}, \mathrm{Cu}}$ は (4)，(5)式にそれぞれの容積 率老垂し加算することによって得られる。

$$
\begin{aligned}
& \sigma_{\mathrm{C}, \mathrm{Cu}}=30.5\left(\bar{\varepsilon}_{f}\right)^{0.182}+20.0\left(\bar{\varepsilon}_{m}\right)^{0.300}, V_{f}=0.25 \\
& \sigma_{\mathrm{C}, \mathrm{Cu}}=48.8\left(\bar{\varepsilon}_{f}\right)^{0.182}+16.0\left(\bar{\varepsilon}_{m}\right)^{0.300}, V_{f}=0.40
\end{aligned}
$$

また $\mathrm{Mo} / \mathrm{Cu}-\mathrm{Cr}$ 複合材料の真応力は

$$
\sigma_{\mathrm{C} . \mathrm{Cu}-\mathrm{C}_{\mathbf{r}}}=30.5\left(\bar{\varepsilon}_{f}\right)^{0.182}+38.9\left(\bar{\varepsilon}_{m}\right)^{0.231}, V_{f}=0.25(9)
$$$$
\sigma_{\mathrm{C}, \mathrm{Cu}-\mathrm{Cr}_{\mathrm{r}}}=48.8\left(\bar{\varepsilon}_{f}\right)^{0.182}+31.1\left(\bar{\varepsilon}_{m}\right)^{0.231}, V_{f}=0.40(10)
$$

ただし、Mo 線は界面に Mo-Cr 固溶体曆を形成しても,Mo 線本来の底力一雨曲線に従うものと仮定した（7)～(10) 式は，圧延於よび引張での变形量の和を引張応力に対応さ 世たものであるが，引張試験は压正加工を加えた試料につ いて行なっているため，引張强さは经された試料の断面 積を基準にして算定しなければならない、そのためここで は簡単のため引張試験による伸びは圧延による相当塑性歪 に比して小さく無視できるものとし，压延による相当塑性 歪を(7)〜(10)式に代入して引張強さを求めることにした (実際にせ九いの整列方向に平行に压延した試料の相当塑 性雪は 50\%以上の加工率では約 50\%以上であるのに対 し，引張試験による饰びば数\%以下であった)。この方法は 引張による試料の断面積変化と応力增加老製視し，引張試 料の压延時のせんいとマトリックスのそれぞれの純粋変形 抵抗に容積率を乗じ加算した值で引張強さを近似寸ること を意㷛している。

本実駖ではせんいに平行に压超した場合は，せんいとマ

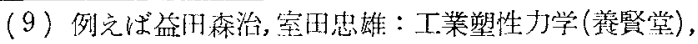
114.
トリックスの変形量はほぼ同じであるから $\bar{\varepsilon}_{f} \fallingdotseq \bar{\varepsilon}_{m}\left(\fallingdotseq \bar{\varepsilon}_{c}\right)$ と 考学ることができ複今材料の相当塑性瑟 $\bar{\varepsilon}_{\mathrm{c}}$ を(7) (10) 式の $\bar{\varepsilon}_{f} ， \bar{\varepsilon}_{m}$ k代入した， $\bar{\varepsilon}_{\mathrm{o}}$ は压延に上り变形した值方体 の形をした複合材料の各辺の塑性歪 $\bar{\varepsilon}_{1}, \bar{\varepsilon}_{2}, \bar{\varepsilon}_{3}$ を測定し，

$$
\bar{\varepsilon}_{\mathbf{c}}=\sqrt{2} / 3 \sqrt{\left(\bar{\varepsilon}_{1}-\bar{\varepsilon}_{2}\right)^{2}+\left(\bar{\varepsilon}_{2}-\bar{\varepsilon}_{3}\right)^{2}+\left(\bar{\varepsilon}_{3}-\bar{\varepsilon}_{1}\right)^{2}}
$$

から計算した。

せんいに直伊に正延した場令は前述のごとく，せんいよ りもマトリックスのすべり系怔大きく働くため, $\bar{\varepsilon}_{f} \neq \bar{\varepsilon}_{m}$ であり， $\bar{\varepsilon}_{f} ， \bar{\varepsilon}_{m}$ の推定は困難であるから $(7) \sim(10)$ 式は实 際に適用することができない，そのため(1)式の $\sigma_{f}$ に加 工後の複合材料中の世んいのビッカース硬度からの推定值

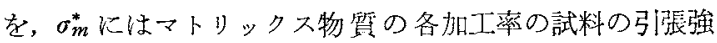
さ $\sigma_{m u}$ 代入することにし，引䟴強さは

$$
\sigma_{c}=\sigma_{f} V_{f}+\sigma_{m u} V_{m}
$$

なる式で推定することにした，日延をらけた複合材料はせ いいの整列方向と平行に引浸試験を行ならから弓张による 变形挙動はほぼ混合則に従うと考光られる(5)。したがって (12)式は，せんいの引張強さ $\sigma_{f}$, 世んい破断倩のマトリッ

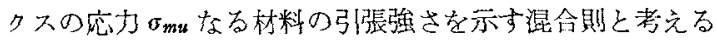
ことができる。

以上の考方方を用いて引㖘強さ推定し，央測值と比較 检尌する。

\section{（1）純銅をマトリックスとした場合}

过九いの整列方向に平行に厈延した $\mathrm{Mo} / \mathrm{Cu}$ 複合祆料で 以常に注洼泥合則が成立するため $(7),(8)$ 式に $\bar{\varepsilon}_{f}=\bar{\varepsilon}_{m}=\bar{\varepsilon}_{c}$ を代入す玌ば引㖘強さは推定できるはずである，Fig.11， Fig.12に(4)(5)(7)(8)式を点線で示し，あわせて実 線で実測值を示した。Fig.11は

$$
\bar{\varepsilon}_{\mathfrak{c}}=\ln \left(1+e_{\mathrm{c}}\right)
$$

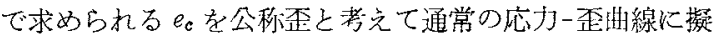
して引张強さを公称霆に対してプロットしたすの，Fig.12 は加工率に対してプロットしな扎したものであり， $\mathrm{Mo} / \mathrm{Cu}$ 複合村料では(7)(8)式の混合則で予想される引張強さと

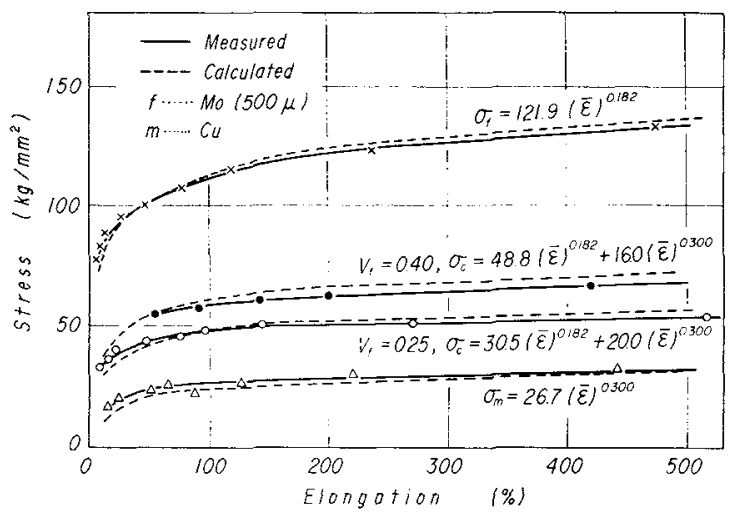

Fig.11 Hypothetic stress-strain curves. Equivalent plastic strain caused by cold rolling parallel to fibres is assumed to be identical to that caused hypothetically by tensile testing 


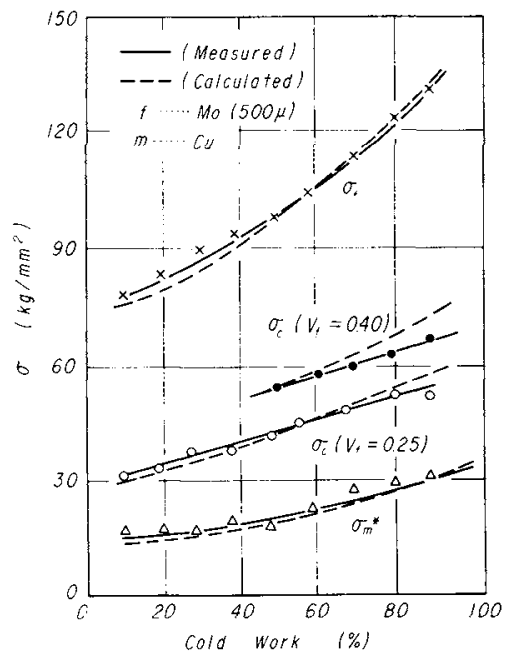

Fig. 12 Comparison of the measured tensile strength of $\mathrm{Mo} / \mathrm{Cu}$ composites cold rolled parallel to fibres with the strength calculated from the equations,

$\sigma_{c}=30.5(\bar{\varepsilon})^{0.182}+20.0(\bar{\varepsilon})^{0.300}$ for $V_{f}=0.25$ $\sigma_{c}=48.8(\bar{\varepsilon})^{0.182}+16.0(\bar{\varepsilon})^{0.300}$ for $V_{f}=0.40$

実測值とはかなり良く一致している。しかし Fig.4に示し たごとく，せんいの破断はわずかではあるがおこっている

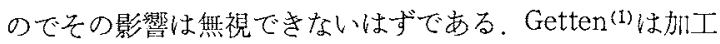
複合材料の Rosenのモデルを悠正した湹合則から敦かれ た $\sigma_{\mathrm{c}}$ より害测值分大きいことを見出しているが，このこと は本実駼でみられる，记んいの破断にもかかわらずはぼ䀝 合則に近い值をとるといら事实と関係があるかもしれな いただし Getten の用いているのは降伏を示さずに破断 するボロンせんいであるから破唗洔にせんいとマトリック スのポアソン比の差に起因する大きな3檕応力をらけてい

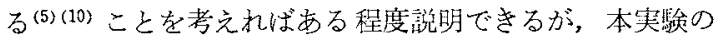
$\mathrm{Mo} / \mathrm{Cu}$ 複会材料ではせんい、降伏伸び以上の伸びが引接

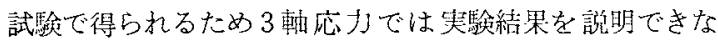
い，前加工によるせんいの破断箘所が緩衝作用の役割を果

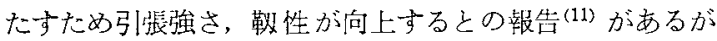
本䇛験でも同じ效果があるか毛しれない。なおFig.11， Fig. 12 の加工率の小さい部分で実測値が計算值より大き いのは計算值を引張試験での伸びを無視して求めたためと 思和々。

Fig.13はせんいの整列方向と宿角に生姃した場合でMo 線の引张強さの推定值 $\sigma_{f}$ と $\mathrm{Cu} の$ 庄延後の引張強さの垁 测值 $\sigma_{m u}$ 此よび複合材料の引張強さの実測值を実線で,

(12)式からの-想值を点線で示したものであり。寒测值と

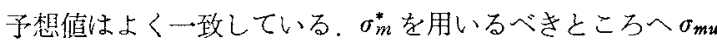
を用いたにもかかわらず笑測檤と予想値がよく一致するの

(10) A. Kelly and H. Lilholt : Phil. Mag., 20 (1969), 311.

(11) J.Mullin, J. M. Berry and A. Gatti : G. E. Tech. Int.Series, R 57 SD 51 (1967).
は，引張試駼による複含材料の破断件びがマトリックスの 破断伸びに近うけけば $\sigma_{m}^{*}$ は $\sigma_{m u}$ に近うくこと，拉よびとく にやんいの整列打向に直角に压延した場合にはマトりック スは単独の加工時より同じ加工率でも大きな率形をうけて いることが原因と思われる。

以上の結果，維銅をマトリックスにした場含は，せんいの 整列方向に平行，直角いずれの力向に压延しても加工によ る複合材料の劣化は少なく，也んいとマトりックスの加工 硬化を考熱した混合則で予想される引張強さは实測値とよ く一致すること，またとくにせんいの整列响に平行に压 延した場合は，引張強さは各加卫率でのせんいとマトりッ クスの純粋変形抵抗を混合則にもとついて加算した值とよ く一致することが琶めら机た。このことは(ハ)〜(ス)が， $\mathrm{Mo} / \mathrm{Cu}$ 複今材料においては引泟強さを低下させる因子と はなっていないことを示している。

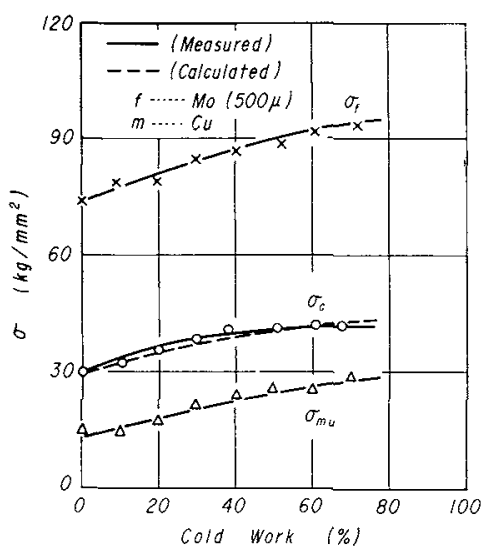

Fig. 13 Comparison of the measured tensile strength of $\mathrm{Mo} / \mathrm{Cu}$ composites with the strength calculated from the equation, $\quad \sigma_{c}=\sigma_{f} V_{f}+\sigma_{m u s} V_{m}$ The composites were cold rolled perpendicular to fibres

\section{（2）Cu-Cr 合金をマトリックスとした場合}

世九いの整外方向に平行に王延した場合む，直角に死延 した場合も引張強さは混合則で想されるより低い値を示 した. Fig.14はFig.8のせんいに平行に王延した複合材料 の引張強さの実験值と混合則からの予想值，および $\sigma_{m}^{*} V_{m}$ を40\%以上の加工戠に対して示したものである。実験值 の下限は，80\%以上の加工承では $\sigma_{c}<\sigma_{m}^{*} V_{m}$ となり，せ 心いの住在は，かえって複合材料の引张強さを低下させて いる.

次に(ハ)〜(ヌ)のららどの因子が冷間正延加工された $\mathrm{Mo} / \mathrm{Cu}-\mathrm{Cr}$ 複合材料の引张強さを经合則で予想される值よ り低下させるか省推定する，せ九いの压延に上る伸びは複 合材料の伸びとほぼ等しくV $V_{f}$ はほぼ一定であることから $\mathrm{Mo} / \mathrm{Cu}$ 複全材料と同じく(二),(一)が,ささらに，小さい加工 率では（チ）考えられるが大きな加工率では，かえって残 


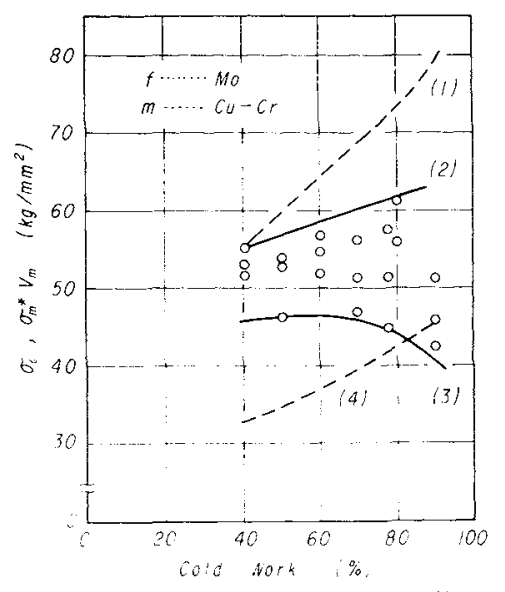

Fig. 14 Comparison of the measured tensile strength of $\mathrm{Mo} / \mathrm{Cu}-\mathrm{Cr}$ composites cold rolled parallel to fibres with the calculated $\sigma_{c}$ and $\sigma_{m}^{*} V_{m}$

(1) $\sigma_{c}$ calculated assuming rule of mixture

(2) Upper bounds of the measured tensile strength

(3) Lower bounds of the measured tensile strength

(4) $\sigma_{m}^{*} V_{m}$

贸応力は大きくなることから(チ)が除外される。集合組織 は引㨬強さに影留を与えるが低下させる原因とはなり得な い. $\mathrm{Mo} / \mathrm{Cu}$ と $\mathrm{Mo} / \mathrm{Cu}-\mathrm{Cr}$ 複合材料の湋いの一つは, 後者

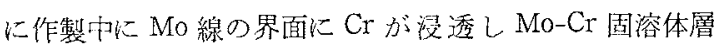
が生成されることである(5)。この Mo-Cr 固溶体層は Mo

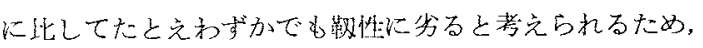
加工中に Mo 線よりもはやく破壊す石可能性がある。奏証 は得られなかったが，この複合材料の庄延及びその後の引 張によるせんいの提伤はおそらくこの Mo-Cr国溶体層の 破藵に起因するものが多いと思われる（八)は損傷部の存

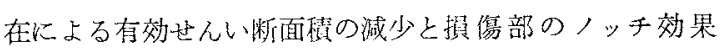
によるものが䓔觉られるが，前者はCr の浸透深さがせん い晰面積に比してわずかである(5)から一応無視できると し，(八)は(ホ)に起因するとする。この結果(ホ)，(ト）お よび(リ)が可能性をもつものとして残る。 $\mathrm{Cu}-\mathrm{Cr}$ 合金は強

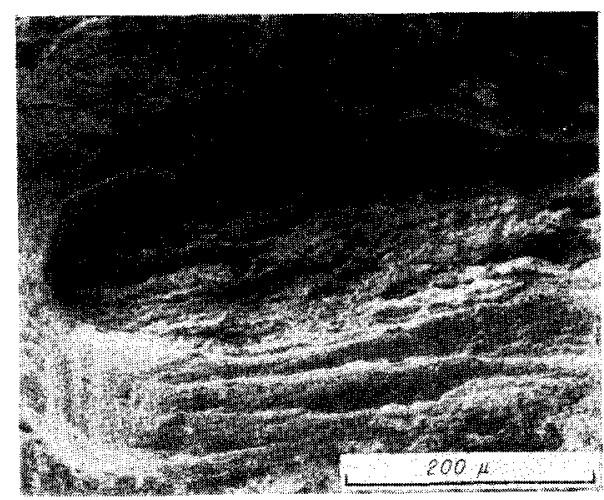

Photo.6 Appearance of fracture surface of $\mathrm{Mo} / \mathrm{Cu}-\mathrm{Cr}$ composite cold rolled $80 \%$ parallel to fibres
加工をらけると，純鈞汇比して䩒性が低下することは予想 される. Photo.6 は $80 \%$ 加工された $\mathrm{Mo} / \mathrm{Cu}-\mathrm{Cr}$ 複合秋料 の破断面であるが，マトリックスはせんいの破断部からの クラックを阻止しているとは考えられない、をた，せんい の破断部の存在は銅がマトリックスのときは引张強さに影 響を与えなかったが，Cu-Cr合金がマトリックスの場会は 影響をおよばす可能性は除外でさない，また残留心力は夕 ラックの発生, 伝播のおこりやすい状沿をつくっているか bしれない.

以上の結果，冷間任延加工された $\mathrm{Mo} / \mathrm{Cu}-\mathrm{Cr}$ 複合材料 の引張強さの低下は，加工によるせんいの破断部またはせ んいの損傷部での応推中の結果叔こるせんいの破断部が 複合材料中のクラックとなり，その先親を゙応力集中をら け，クラック阻此能力の低下したマトリックス中へ伝播し 複合材料は破断に至るとの推定が本实験では最可可能性が ある、またこの場合，残留念力がクラックの発生，伝播を 促進する可能性すある。

せんい周囲の Cr 固溶体層の破壊仕加工を加える場合は さけられないと思われるが，せ九いの配列や加工条件など

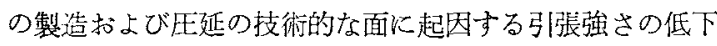
はさけられるはずであり，后はさらに上昇させることので きる可能性はある。Fig.8，Fig.9のバラッキの原因は前述 のごとく技術的なるのだけではないが，せんいの損鹪を最 小限に押えて上限値を常に再現できれば複合化，待効硬 化, 加工硬化の三つの強化法の使用はこのうちの二つの強 化法の併用より埛い引張強さを与えることができるはずで ある。

\section{V. 総 括}

せえいに Mo 怙よびW線、マトリックスに純銅抢よび時 效性 $\mathrm{Cu}-\mathrm{Cr}$ 合金を用いて調製し，冷間压延加工を加壳た 世九い強化複合材料の変形举動と弓㖘強さを調へ次の結果 光得た。

(1) $\mathrm{Mo} / \mathrm{Cu}$ 複合材料では，好んいの整列力向に平行に 生延した場合はせんいとマトリックスの変形量はほぼ等し いが，直角に艮延した場合は，せ九いに比してマトリック スの変形量が大きいことが眧められ，マトリックスのすベ りのおこりやすさの差がその湶因と推定された。

引輩強さはせんい平行に代延した場合は純粋変形抵抗 の鼠合則から尔想される応力を，引第試駼での保びが小さ

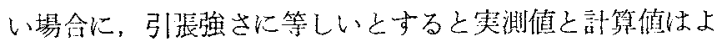

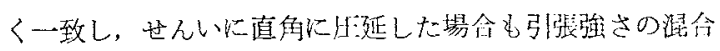
賥で予想される值とよく一致した。

(2) $\mathrm{Mo} / \mathrm{Cu}-\mathrm{Cr}$ 複合材料の加工による変形举動はマクロ

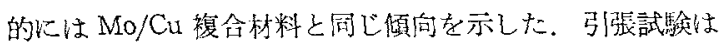
混合則で子想される值を下まわり，ある場合には婪んいの 存在はかえって引張強さを低下させた。これは垃んいの掑 傷, 破断部での応力集中と, マトリックスのクラック阻止 
能力の低下拉よび残留応力の存在が原因と推定された。

(3) W/Cu 複合材料の加工では孙んいの破断が著しく, 世九い、平行，直角いずれの方向に圧延しても30４0\% の加工率で最大引張強さを示し，それ以上の压延加工は引 張強さを低下させた。せんいに平行炕压延した場合はW線 はマルティプルネッキングを示した。
本実験結果の塑性加工学的な取り报いちについて有益な 御助言をいただきした京都大学工学部 大矢根守哉教授, SEM 観察に御協力いただき李した当研究室の長村光造 博士, 実験に御協力いただき立した山中 肇技官, 種々御援 助いたださるした住友軽金属工業株式会社拉よび日本銅セ ンター複合材料委員会に深謝致します。

\section{封着用 $\mathrm{Fe}-18 \mathrm{Cr}$ 合金の酸化膜の電気抵抗に およ㴗す $\mathrm{Al}, \mathrm{Ti}$ 添加の影響*}

$\begin{array}{lllllll}\text { 久 世 } & \text { 孝** } & \text { 平 } & \text { 秀 } & \text { 夫** }^{* *} \\ \text { 幕 内 } & \text { 昭 } & \text { 司 } & \text { 平 } \text { 沢 康 } & \text { 伸** }\end{array}$

Takashi Kuse, Hideo Hirayama, Teruji Makuuchi and Yasunobu Hirasawa : Effects of Additions of $\mathrm{Al}$ and $\mathrm{Ti}$ on Electrical Resistivities of Oxide Films of Fe-18 Cr Sealing Alloy. $\mathrm{Fe}-18 \mathrm{Cr}$ sealing alloys containing $\mathrm{Al}$ and $\mathrm{Ti}$ have been prepared by vacuum melting, and oxidized in air and wet hydrogen. The electrical resistivities of the oxide films on the alloys have been measured. Mutual relations between the electrical resistivity and structure, morphology of the oxide film, interface between the metal and the oxide film have been investigated. The results obtained are as follows.

(1) Electrical resistivities of the oxide films on the alloys oxidized in air are not affected by the additions of $\mathrm{Al}$ and/or $\mathrm{Ti}$, and are in the range of $10^{3} \sim 10^{4} \Omega-\mathrm{cm}$. In the case of oxidations in wet hydrogen, electrical resistivites of the oxide films on the alloy which was not added and alloy containing $\mathrm{Al}$ and $\mathrm{Ti}$ are in the range of $10^{3} \sim 10^{4} \Omega-\mathrm{cm}$, but the alloys containing $\mathrm{Al}$ or Ti alone show the electrical resistivities of $10^{7} \sim 10^{10} \Omega$-cm and $10^{5} \sim 10^{9} \Omega$-cm respectively.

(2) By the heat treatment in air after the oxidation in wet hydrogen, the electrical resistivity of the oxide films on the alloys containing $\mathrm{Al}$ or $\mathrm{Ti}$ alone or none of them increases with the temperature of heat treatment. But the resistivity for alloys containing $\mathrm{Al}$ and $\mathrm{Ti}$ increases with the temperature of heat treatment and shows a maximum at $1000^{\circ} \mathrm{C}$, and beyond this critical temperature, it becomes to smaller than the initial value.

(3) Electrical resistivity of oxide films is supposed to change by the structure, charge carrier density and the increase or decrease of metal and oxygen ions.

(Received November 16, 1972)

\section{I. 緒言}

前報(1)で鞍質ガラス封着合金として用いられる $\mathrm{Fe}$-18 Cr 合金について封着性の良い予備酸化膜を作るための処理条 件を梌討するため大気中および湿潤水素中で高温酸化した 結果について報告した，Fe-18 Cr 合金の場合，大気中で高 温酸化してもがラス封着は可能であるがより信賴性の高い 封着構体を得るためには湿潤水素中で高温酸化し，安定な 酸化膜を得る必要がある。

封着合金はその性質上，絶縁物であるガラス容器の内部 と外部を電気的に接続する導入金属として使用される。こ のとき，封着時に要求された酸化膜を介して，あるい酸 化膜を除去して導体金属と接続されるが，酸化膜を介して

***東京芝浦電気株式会社金属材料事業部(Metal Product Division, Tokyo Shibaura Electric Co., Ltd, Kawasaki)

* 1972 年 10 月金属学会名古屋大会に発表
接合する場合，その電気抵抗が高いと当然電化降下をきた し, 電気回路設計上支障をきたすため接触抵抗も含めて電 気抵抗が問題となる．Fe- $18 \mathrm{Cr}$ 合金の酸化膜の除去は容易 ではないため，電気抵抗の低い酸化膜を持った $\mathrm{Fe}-18 \mathrm{Cr}$ 合金が要求される。

$\mathrm{Fe}-18 \mathrm{Cr}$ 合金を大気中で高温酸化したときは電気抵抗 の比較的低い酸化膜が得られていた。より封着信賴度の高 い酸化膜を得ようとするとき湿潤水素中で高温酸化する必 要がある。そこで湿潤水素中で得た高温酸化膜について基 本的な特性を調べるとともに添加元素の酸化膜の電気抵抗 そおよばす影響について調べてみた。

\section{II. 試料および実験方法}

\section{1. 試料}

供試料は真空溶解により作成したTable 1 亿示寸組成

（1）久世 孝, 岩井直次, 幕内昭司: 金属学会誌, 37 (1973), 278 . 